\title{
Sintesis Merkaptoetil Karboksilat sebagai Bahan Baku Stabiliser Termal Polivinil Klorida: Variasi Sumber Asam Lemak
}

\author{
I Dewa Gede Arsa Putrawan ${ }^{1, *}$, Adli Azharuddin ${ }^{2}$, Dendy Adityawarman ${ }^{3}$, Dicka Ar Rahim ${ }^{4}$ \\ ${ }^{1}$ Kelompok Keahlian Perancangan dan Pengembangan Produk \\ ${ }^{2}$ Program Studi Magister Teknik Kimia \\ ${ }^{3}$ Kelompok Keahlian Perancangan dan Pengembangan Proses \\ ${ }^{4}$ Kelompok Keahlian Energi dan Sistem Pemroses \\ Fakultas Teknologi Industri, Institut Teknologi Bandung, Jalan Ganesha 10, Bandung 40132 \\ *e-mail: idewa@che.itb.ac.id
}

\begin{abstract}
Abstrak. Merkaptoetil karboksilat merupakan bahan baku stabiliser termal polivinil klorida atau polyvinyl chloride $(P V C)$ berbasis timah organik. Stabiliser termal perlu ditambahkan ke dalam resin PVC sebelum diekstrusi untuk mencegah kerusakan karena pengerjaan panas. Stabiliser termal PVC dari timah organik dikenal sangat efektif, khususnya untuk aplikasi PVC kaku seperti pipa dan bingkai jendela. Penelitian ini bertujuan mengevaluasi sintesis merkaptoetil karboksilat dari asam lemak dan merkapto etanol dengan variasi sumber asam lemak yang meliputi asam lemak sawit, dedak padi dan biji kapuk. Percobaan dilakukan dalam sebuah reaktor partaian (batch) dengan asam kuat sebagai katalis. Percobaan dilakukan pada temperatur $60-80^{\circ} \mathrm{C}$ dan ekses merkapto etanol $10 \%$. Kinerja sintesis dievaluasi melalui pengukuran kadar gugus merkaptan dan angka asam dalam produk serta perolehan produk. Pada rentang temperatur $60-80^{\circ} \mathrm{C}$, ketiga asam lemak memberikan produk dengan kadar merkaptan pada rentang 6,4-7,8\%. Temperatur $70^{\circ} \mathrm{C}$ merupakan temperatur terbaik karena menghasilkan produk dengan kadar merkaptan tertinggi tanpa memadat selama penyimpanan. Pada temperatur ini, produk memiliki angka asam pada rentang $11-41 \mathrm{mg} \mathrm{KOH/g} \mathrm{dan}$ perolehan pada rentang 70-81\%. Ketiga sumber asam lemak memberikan produk dengan kadar merkaptan yang mencukupi untuk dapat digunakan sebagai bahan baku stabiliser PVC. Mempertimbangkan kualitas produk dan ketersediaan di pasaran, distilat asam lemak sawit dipandang sebagai bahan baku yang paling baik.
\end{abstract}

Kata kunci: asam lemak, merkaptoetil karboksilat, polivinil klorida, stabiliser termal.

\begin{abstract}
Synthesis of Mercaptoethyl Carboxylate as Raw Materials for Polyvinyl Chloride Thermal Stabilizer: Variation in Fatty Acid Source. Mercaptoethyl carboxylate is a raw material for organotin-based polyvinyl chloride $(P V C)$ thermal stabilizer. Thermal stabilizers need to be added to the PVC resin before extruded to prevent degradation due to heat treatment. Organotin PVC stabilizers are known to be very effective, especially for rigid PVC applications such as pipes and frames. This study was aimed to evaluate the synthesis of mercaptoethyl carboxylate from fatty acids and mercaptoethanol with various sources of fatty acids including palm, rice bran and kapok seed fatty acids. The experiment was carried out in a batch reactor with a strong acid as a catalyst. The experiments were conducted at 60$80^{\circ} \mathrm{C}$ and $10 \%$ mercapto ethanol excess. The performance of synthesis was evaluated by measuring mercaptan and acid contents and yield. In the range of $60-80^{\circ} \mathrm{C}$, all three fatty acids provided products with mercaptan levels in the range of 6.4-7.8\%. A temperature of $70^{\circ} \mathrm{C}$ is the best temperature as it gave a product with the highest mercaptan content without solidification during storage. At this temperature, the product had acid values in the range $11-41 \mathrm{mg} \mathrm{KOH} / \mathrm{g}$ and yields in the range of 70-81\%. Considering product quality and availability in the market, palm fatty acid distillate was seen as the best raw material.
\end{abstract}

Keywords: fatty acid, mercaptoethyl carboxylate, polyvinyl chloride, thermal stabilizer.

\section{Graphical Abstract}

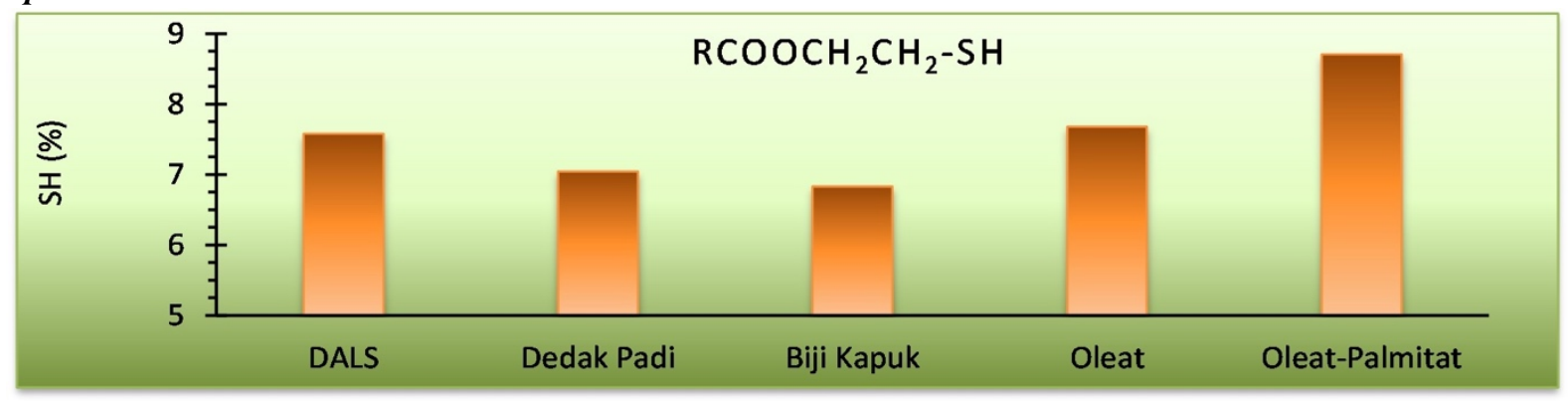




\section{Pendahuluan}

Polivinil klorida atau polyvinyl chloride (PVC) merupakan polimer terbesar ketiga di dunia dalam jumlah produksi setelah polietilen dan polipropilen (Carraher, 2013). Konsumsi global PVC pada tahun 2016 mencapai 42 juta ton dan diperkirakan akan meningkat sebanyak 3,2\% per tahun hingga 2024 (Ceresana, 2017). Tambahan pula, Asia-Pasifik merupakan pasar terbesar, sekitar 56\% dari pasar global. Sebagian besar aplikasi PVC berada di sektor konstruksi, meliputi pipa, atap, lantai, dinding, pembungkus kabel, dan sebagainya. Walaupun menguasai beragam aplikasi, PVC memiliki sebuah kelemahan, yakni mengalami degradasi karena panas (Wirth dan Andreas, 1977). Degradasi PVC oleh panas dinamakan degradasi termal. Penyebab utama degradasi termal adalah keberadaan klorida alilik dalam PVC. Klorida alilik sangat labil dan mudah lepas oleh panas menghasilkan hidrogen klorida. Degradasi termal PVC merupakan sebuah proses autokatalitik. Hidrogen klorida yang terbentuk mengatalisis dan mempercepat pelepasan hidrogen klorida berikutnya. Jika degradasi tidak dicegah, PVC berubah menjadi poliena dan menjadi gelap serta rapuh sehingga tidak dapat dibentuk. Degradasi termal menjadi masalah yang serius karena aplikasi PVC melibatkan proses pemanasan.

Stabiser termal merupakan aditif yang ditambahkan ke dalam PVC untuk mencegah degradasi termal. Stabiliser termal PVC umumnya berupa senyawa logam organik dari timah $(\mathrm{Sn})$, timbal $(\mathrm{Pb})$, atau logam campuran, kalsium/seng $\mathrm{Ca} / \mathrm{Zn}$ dan barium/seng $\mathrm{Ba} / \mathrm{Zn}$ (Wypych, 2008). Di tingkat global, stabiliser berbasis timbal menempati pasar terbesar (Wallenwein, 2006). Akan tetapi, masalah lingkungan telah menggeser penggunaan timbal. Timah organik merupakan stabiliser termal PVC yang sangat efektif, khususnya untuk PVC kaku, khususnya pipa, serta mulai mengambil pasar logam timbal. Berdasarkan unsur penyusunnya, stabiliser timah organik terbagi menjadi dua, yakni non-sulfur untuk stabilisasi radiasi dan merkaptida (mengandung sulfur) untuk stabilisasi termal. Kelompok merkaptida dibagi menjadi dua, yakni ester (untuk aplikasi transparan/lembaran/pangan) dan ester-balik atau reverse-ester (untuk aplikasi buram/ekstrusi/non pangan). Stabiliser ester-balik merupakan kelompok timah organik yang sangat popular dan efektif untuk pipa PVC karena menjadikan resin PVC tahan gaya geser (ekstrusi).

Stabiliser ester-balik diproduksi melalui dua tahap sintesis senyawa, yakni: sintesis merkapto etil karboksilat dan sintesis metil timah merkapto karboksilat sulfida. Merkapto etil karboksilat dibuat melalui esterifikasi merkaptoetanol (ME) dan asam lemak bebas (ALB). Hasil reaksi dinamakan ester-balik karena gugus merkaptil berasal dari sisi alkohol, berbeda dengan kelompok ester yang diturunkan dari merkaptil yang melekat pada asam lemak. Sumber ALB yang populer saat ini adalah TOFA (tall oil fatty acid), produk samping pabrik kertas berbahan baku kayu pinus. Akan tetapi, ketersediaan TOFA dunia mulai terbatas sebagai akibat dari kerusakan lingkungan sehingga dibutuhkan sumber ALB alternatif. Dalam mencari alternatif bahan baku, hasil samping industri pertanian patut dilirik untuk meningkatkan nilai tambah sekaligus untuk mengurangi masalah lingkungan. Tiga sumber asam lemak yang dipandang dapat dimanfaatkan untuk produksi merkapto etil karboksilat adalah distilat asam lemak sawit, dedak padi dan biji kapok.

Distilat asam lemak sawit (DALS) atau dikenal dengan nama Palm Fatty Acid Distillate (PFAD) merupakan produk samping proses pemurnian minyak sawit (Top, 2010). DALS merupakan campuran ALB, berwarna kuning (kadang kecoklatan), berwujud padat pada temperatur kamar. DALS diperdagangkan dengan harga lebih rendah dari refined-bleached-deodorized (RBD) bahkan lebih rendah dari minyak sawit mentah (CPO) karena dipandang sebagai produk samping. Sebagai contoh, pada Agustus 2015 (FOB Belawan/Dumai), CPO dihargai 515 USD/ton sedangkan DALS dihargai 353 USD/ton (Palm Oil Analytics, 2019). Produksi DALS di Indonesia diperkirakan mencapai 1,2 $-1,5$ juta ton/tahun. DALS saat ini dimanfaatkan untuk aplikasi non-pangan, seperti sabun, pakan ternak dan bahan bakar industri. Dedak padi merupakan hasil samping proses penggilingan padi. Produk samping ini mengandung $8 \% \mathrm{~s} / \mathrm{d} 10 \%$ minyak/lemak. Minyak dedak padi sebenarnya merupakan minyak pangan sehat karena mengandung $\gamma$-oryzanol, senyawa antioksidan yang mampu menurunkan kolesterol berbahaya (Ali dan Devarajan, 2017; Patel dan Naik, 2004). Akan tetapi, aktivitas enzim lipase menyebabkan dedak padi mudah tengik. Pengolahan dedak padi tanpa destabilisasi lipase menghasilkan minyak yang mengandung sejumlah besar ALB dan menjadi tidak ekonomis untuk dimurnikan menjadi minyak pangan. Biji kapuk merupakan produk samping pengolahan buah kapuk menjadi serat. Biji kapuk mengandung $\pm 20 \%$ minyak dengan kadar asam lemak tak jenuh yang tinggi (mencapai 60\%). Minyak biji kapuk mengandung 13\% asam-asam siklopropen (malvalik dan sterkulik) sehingga tidak baik untuk dikonsumsi sebagai minyak pangan. Luas lahan pohon kapuk di Indonesia pada tahun 2014 mencapai 144 ribu ha (Badan Pusat Statistik, 2018). Dengan perolehan biji 0,9-1,4 ton/ha (Anigo dkk., 2013), produksi biji kapuk Indonesia diperkirakan mencapai 130-202 ribu ton/tahun. Upaya pemanfaatan minyak biji kapuk saat ini adalah sebagai bahan baku biodiesel (Erliyanti, 2016; Vedharaj dkk., 2013; Fajar dan Hendrawati, 2015).

Sintesis merkapto etil karboksilat telah disinggung sejak lama oleh Leistner dan Hecker (1959). Reaksi melibatkan katalis asam dengan air sebagai produk samping. Dengan beberapa asam lemak murni, Sonnet dan Moore (1989) memperoleh campuran O-ester dan Sester. Dengan asam oleat, Wang dkk. (2012) menemukan bahwa penguapan menjadi pilihan terbaik untuk mengusir air (produk samping). Putrawan dkk. (2018) mengkaji pembuatan merkapto etil karboksilat dari DALS. Belum ada peneliti yang membandingkan hasil sintesis merkapto etil karboksilat dari berbagai sumber ALB. Untuk meningkatkan peluang perolehan alternatif pengganti TOFA sebagai bahan baku merkapto etil karboksilat, sintesis dengan berbagai sumber ALB perlu dikaji. Penelitian ini diarahkan untuk mengevaluasi sintesis merkapto etil karboksilat dari ALB dengan 
berbagai sumber ALB. Tiga asam lemak digunakan sebagai bahan baku, meliputi asam lemak sawit, dedak padi dan biji kapuk. Ketiga sumber asam lemak ini merupakan sumber lokal dan termasuk sumber nonpangan sehingga pemanfaatannya tidak menyaingi sektor pangan. Dari sisi komposisi, asam lemak berbasis sawit mengandung asam lemak jenuh dan tak jenuh yang berimbang. Di lain pihak, asam lemak berbasis dedak padi dan biji kapok mengandung lebih banyak asam lemak tak jenuh. Penelitian dilakukan dalam skala laboratorium menggunakan sebuah reaktor partaian (batch). Kinerja sintesis dievaluasi melalui pengukuran kadar merkaptan dan angka asam produk serta perolehan produk. Kadar merkaptan dijadikan ukuran kualitas produk mengingat gugus merkaptida memiliki peran penting dalam stabilisasi termal PVC. Angka asam dapat dijadikan ukuran jumlah ALB yang tersisa. Hasil penelitian diharapkan dapat mendukung produksi stabiliser termal PVC ester-balik. Stabiliser termal jenis ini sangat tepat dikembangkan mengingat bahan baku utama, yakni timah dan lemak, merupakan sumber lokal yang tersedia di tanah air.

\section{Percobaan}

\subsection{Bahan}

DALS diperoleh dari pabrik pemurnian minyak sawit lokal. ALB dedak padi dan biji kapok diperoleh melalui penyabunan dan pengasaman minyak mentah. Minyak dedak padi mentah diperoleh melalui ekstraksi dedak padi menggunakan n-heksana sebagai pelarut. Minyak biji kapuk mentah dibeli dari pemasok lokal. Merkapto etanol dibeli dari Merck, memiliki kemurnian $>99 \%$. pTSA dibeli dari Fluka, memiliki kemurnian $>98 \%$.

\subsection{Prosedur}

Merkapto etil karboksilat disintesis mengikuti prosedur sebelumnya (Putrawan dkk., 2018). Sebuah gelas berjaket dengan volume $60 \mathrm{~mL}$ digunakan sebagai reaktor. Sebanyak $40 \mathrm{~g}$ ALB bersama ME dengan kelebihan ME sebesar 10\%-mol dimasukkan ke dalam reaktor. Temperatur reaksi diatur dengan mengendalikan temperatur air pemanas yang mengalir melalui jaket reaktor. Setelah campuran mencapai temperatur yang diinginkan, katalis dimasukkan ke dalam reaktor, bagian atas reaktor kemudian disambungkan dengan kondenser yang beroperasi pada tekanan vakum. Asam lemak (RCOOH) bereaksi dengan merkapto etanol mengikuti persamaan (1) berikut:

$\mathrm{RCOOH}_{(1)}+\mathrm{HOCH}_{2} \mathrm{CH}_{2} \mathrm{SH}_{(1)} \rightleftharpoons \mathrm{RCOOCH}_{2} \mathrm{CH}_{2} \mathrm{SH}_{(\mathrm{l})}+$ $\mathrm{H}_{2} \mathrm{O}_{(1)}$

Pada bagian akhir, temperatur reaksi dijaga pada $80^{\circ} \mathrm{C}$ untuk memastikan kelebihan $\mathrm{ME}$ dapat disingkirkan. Produk reaksi dicuci, dikeringkan dan disaring. Produk selanjutnya ditimbang dan dianalisis.

\subsection{Analisis}

Kadar merkaptan diukur melalui titrasi iodin mengikuti prosedur dari literatur (Ciesielski dan Zakrzewski, 2006; Critchfield, 1963; Vogel dan Mendham, 2000). Titrasi didasari reaksi antara merkaptan dan iodin menghasilkan ditiol dan hidrogen iodida (persamaan (2)):

$$
2 \mathrm{R}-\mathrm{SH}+\mathrm{I}_{2} \rightarrow \mathrm{RS}-\mathrm{SR}+2 \mathrm{HI}
$$

Angka asam diukur melalui titrasi dengan larutan $\mathrm{KOH}$. Angka iodin diukur dengan metode Wijs. Spektra infrared (IR) diukur dengan spektrofotometer Shimadzu IR-Prestige-21, pada rentang panjang gelombang 4,000 $400 \mathrm{~cm}^{-1}$. Kadar beberapa asam lemak utama sebagai metil ester diukur menggunakan GC MS Shimadzu 2010GCMS-QP2010 Ultra dengan sebuah kolom kapiler RtX ${ }^{\circledR}-5 \mathrm{MS}$ (panjang 30, diameter dalam 0,25 mm, dan ketebalan $0,25 \mu \mathrm{m})$. Temperatur diprogram pada $4^{\circ} \mathrm{C} /$ menit dari 50 hingga $250^{\circ} \mathrm{C}$. Temperatur injektor dan detektor ditetapkan pada $280^{\circ} \mathrm{C}$, dengan helium sebagai gas pembawa. Spektra massa dibandingkan dengan basis data dari Wiley Library 7 dan NIST 8 Library.

\section{Hasil dan Pembahasan}

\subsection{Karakter bahan baku}

Tabel 1 menyajikan karakter ALB yang digunakan. Ketiga asam lemak berwujud padat pada kondisi ruangan. Kadar beberapa asam lemak kunci menunjukkan bahwa ALB dedak padi memiliki kadar asam lemak tak jenuh tertinggi, diikuti biji kapuk dan DALS. Kecenderungan ini juga ditunjukkan dengan jelas oleh nilai angka iodin. ALB dedak padi memberikan angka iodin tertinggi, diikuti dengan biji kapuk dan DALS. Kecenderungan ini juga sejalan dengan nilai titer, dimana DALS memiliki nilai titer tertinggi diikuti biji kapuk dan dedak padi. Titer menggambarkan titik beku asam lemak. Asam lemak jenuh memiliki titer lebih tinggi dibandingkan dengan asam lemak tak jenuh. Semakin tinggi kadar asam lemak jenuh atau semakin rendah angka iodin, nilai titer cenderung semakin tinggi. Angka asam memiliki kecenderungan yang sama dengan angka iodin. Dedak padi memiliki angka asam tertinggi diikuti dengan biji kapuk dan DALS. Kadar asam lemak yang diperoleh masih pada rentang data yang disajikan dalam literatur (Berry, 1979; Chang dkk., 2016; Shahidi, 2005).

\subsection{Karakter produk}

Gambar 1 menyajikan spektra IR produk. Gambar tersebut juga menyajikan spektra merkapto etil karboksilat dari pasar (terbuat dari TOFA) sebagai pembanding. Puncak-puncak penciri struktur merkapto etil karboksilat ditemukan pada panjang gelombang $1165-1167 \mathrm{~cm}^{-1}, 1738-1740 \mathrm{~cm}^{-1}, 2569-2571 \mathrm{~cm}^{-1}$, dan 2851-2924 $\mathrm{cm}^{-1}$ yang secara berturut-turut mencirikan keberadaan gugus $\mathrm{C}-\mathrm{O}, \mathrm{C}=\mathrm{O}$, SH dan $\mathrm{CH}$. Spektra dari ketiga produk sangat identik dengan spektra dari produk yang ada di pasaran. Hal ini menandakan bahwa 
merkapto etil karboksilat berhasil disintesis dari ketiga bahan baku yang digunakan.

\subsection{Kadar merkaptan dan perolehan}

Gambar 2 menyajikan kadar merkaptan dalam produk pada berbagai temperatur reaksi. DALS memberikan kadar merkaptan tertinggi, sementara ALB biji kapuk memberikan nilai terendah. Secara umum, kadar merkaptan meningkat jika temperatur reaksi dinaikkan. Semakin tinggi kadar merkaptan, semakin efektif stabiliser termal yang dihasilkan. Peran gugus merkaptida dalam stabilisasi PVC dapat dilihat di Gambar 3. Klorin alilik yang sangat labil, penyebab utama degradasi, membentuk ikatan koordinasi dengan atom timah yang diikuti dengan pertukaran gugus merkaptida. Pertukaran klorin alilik dengan merkaptida mencegah pelepasan hidrogen klorida dan sekaligus mencegah degradasi termal. Atas dasar kadar merkaptan, sintesis paling bagus dilaksanakan pada temperatur $80^{\circ} \mathrm{C}$. Akan tetapi, pada temperatur ini, produk yang dihasilkan menggumpal ketika disimpan. Fenomena yang sama ditemukan oleh Wang dkk. (2012) yang menggunakan asam oleat sebagai bahan baku. Penyebab penggumpalan tersebut diduga karena reaksi polimerisasi produk yang terjadi pada temperatur di atas $75^{\circ} \mathrm{C}$. Sehubungan dengan hal tersebut, temperatur $70^{\circ} \mathrm{C}$ dipandang sebagai temperatur terbaik.

Tabel 1. Karakter asam lemak bahan baku

\begin{tabular}{cccc}
\hline Parameter & $\begin{array}{c}\text { Distilat } \\
\text { Sawit }\end{array}$ & $\begin{array}{c}\text { Dedak } \\
\text { Padi }\end{array}$ & $\begin{array}{c}\text { Biji } \\
\text { Kapuk }\end{array}$ \\
\hline $\begin{array}{c}\text { Angka Asam } \\
(\text { mg KOH/g) }\end{array}$ & 184 & 196 & 192 \\
Angka Iodin & 54 & 103 & 100 \\
$\left(\mathrm{mg} \mathrm{I}_{2} / 100 \mathrm{~g}\right)$ & & 29 & 34 \\
Titer $\left({ }^{\circ} \mathrm{C}\right)$ & 47 & & \\
Kadar $(\%)$ & & 21 & 29 \\
C16:0 & 33 & 3 & 4 \\
C18:0 & 6 & 42 & 25 \\
C18:1 & 31 & 29 & 29 \\
C18:2 & 15 & &
\end{tabular}

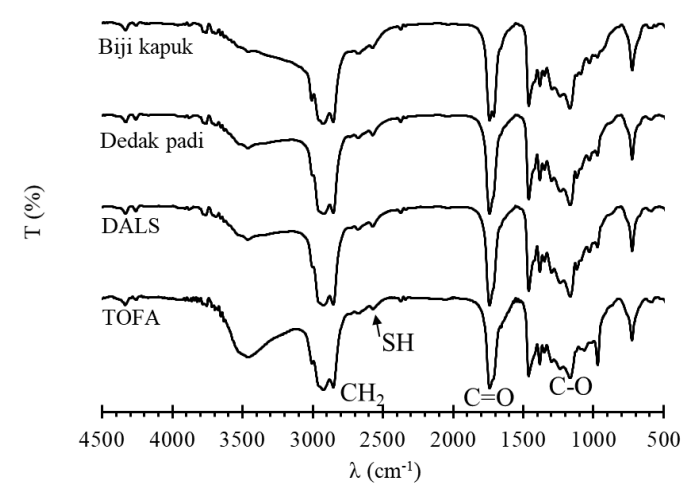

Gambar 1. Spektra FTIR dari produk

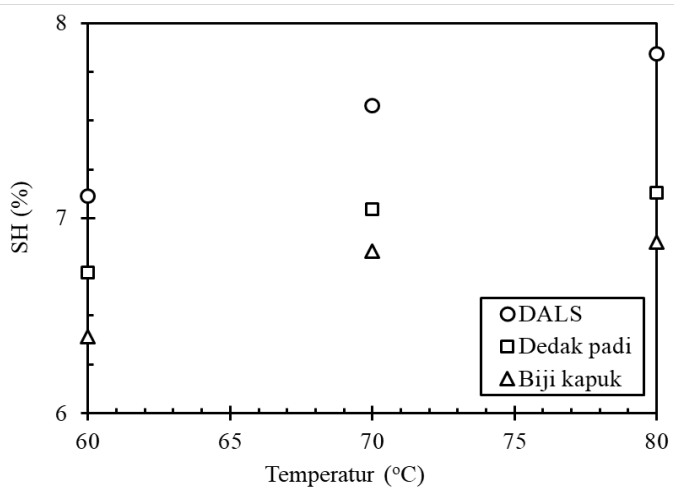

Gambar 2. Pengaruh temperatur terhadap kadar merkaptan dalam produk

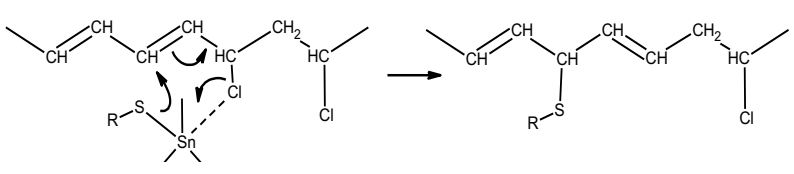

Gambar 3. Mekanisme stabilisasi PVC

Gambar 4, Gambar 5, dam Gambar 6 secara berturut-turut menampilkan dengan lebih jelas pengaruh bahan baku terhadap kadar merkaptan, perolehan dan angka asam produk yang diperoleh pada $70^{\circ} \mathrm{C}$. Di samping ketiga asam lemak yang telah dibahas sebelumnya, gambar-gambar tersebut juga menampilkan hasil untuk asam oleat murni dan campuran asam oleat dan asam palmitat (40\%-b oleat). Hasil-hasil tersebut semakin memastikan bahwa DALS memberikan produk yang lebih bagus dibandingkan dengan ALB dedak padi dan ALB biji kapuk. Baik ALB dedak padi maupun ALB biji kapuk memiliki kadar asam lemak tak jenuh yang lebih tinggi dibandingkan dengan DALS. Capaian kadar merkaptan yang lebih rendah untuk ALB dedak padi maupun ALB biji kapuk diduga terjadi karena merkaptan dari ME berinteraksi dengan ikatan tak jenuh. Merkaptan dapat menyerang ikatan rangkap menghasilkan ikatan thiol-ene dan dimanfaatkan untuk membentuk biopolimer (Machado dkk., 2017). Dugaan ini dapat diperkuat dengan membandingkan kadar merkaptan produk yang diperoleh dengan menggunakan asam oleat murni dan campuran asam oleat-palmitat. Penambahan asam palimitat (jenuh) sebesar $60 \%$ ke dalam asam oleat murni meningkatkan kadar merkaptan dari 7,6 menjadi 8,7. Satu tambahan tempuhan dengan menggunakan ALB TOFA ( $90 \%$ lemak tak jenuh) memberikan produk dengan kadar merkaptan sebesar 7,0\%. Keberadaan reaksi samping menyebabkan capaian kadar merkaptan tidak maksimum. Secara teoritik, kadar merkaptan maksimum berada pada nilai $\pm 9,6 \%$. Nilai ini diperoleh untuk asam oleat murni dengan mengganggap reaksi sempurna menghasilkan merkapto etil oleat. Asam lemak dedak padi mengandung fraksi jenuh lebih sedikit dibandingkan asam lemak biji kapuk, dapat dilihat dari angka iodin, titer, dan komposisi asam lemak. Akan tetapi, asam lemak dedak padi memberikan kadar merkaptan yang lebih besar walaupun perbedaan kadar merkaptan yang ditemukan tidak sebesar perbedaan antara asam lemak sawit dan asam lemak dedak padi/biji 
kapuk. Hasil dengan kedua sumber asam lemak ini memunculkan dugaan bahwa, di samping tingkat kejenuhan asam lemak, komponen minor dalam sumber asam lemak juga berpengaruh terhadap capaian kadar merkaptan dalam produk.

Pengamatan terhadap kadar merkaptan sejalan dengan hasil pengamatan terhadap angka asam. Dalam hal ini, ALB biji kapuk yang memberikan angka merkaptan terendah, diketahui memiliki angka asam tertinggi. Pengukuran angka asam untuk menyatakan sisa ALB (bahan baku) yang tidak terkonversi menjadi produk sebenarnya kurang akurat karena perubahan warna fenolftalein dalam menentukan titik ekivalen sulit diamati karena produk berwarna kecoklatan. Sehubungan dengan hal tersebut, penentuan titik ekivalen dalam penelitian ini dilakukan dengan memantau $\mathrm{pH}$ campuran selama titrasi. Gambar 7 menampilkan profil pH selama titrasi untuk merkapto etil karboksilat dari ALB biji kapuk sebagai sampel produk dan asam oleat sebagai sampel bahan baku. Berbeda dengan ALB (asam oleat dalam hal ini) yang menunjukkan peningkatan $\mathrm{pH}$ yang tajam di titik ekivalen, produk (merkapto etil karboksilat) hanya memperlihatkan kenaikan yang pendek sehingga menuntut kehati-hatian dalam menentukan titik ekivalen. Terlepas dari ketelitian pengukuran yang terbatas, nilai angka asam, bersama kadar merkaptan, dapat memberikan gambaran bahwa ALB dari asam lemak sawit, dedak padi, dan biji kapuk berhasil dikonversi menjadi merkapto etil karboksilat. Pada $70^{\circ} \mathrm{C}$, ketiga bahan baku memberikan kadar merkaptan 6,8-7,5\%. Sampel produk yang diperoleh dari pasar yang digunakan sebagai bahan baku stabiliser termal ester-balik diketahui memiliki kadar merkaptan 6,7\%. Dengan demikian, merkapto etil karboksilat yang dihasilkan dari ketiga bahan baku yang dikaji telah memenuhi kebutuhan spesifikasi di pasaran. Mempertimbangkan bahwa DALS telah diproduksi dalam skala industri di tanah air dan telah tersedia dalam bentuk ALB tanpa memerlukan proses penyabunan, DALS dipandang debagai bahan baku yang lebih potensial dibandingkan ALB dedak padi dan biji kapuk.

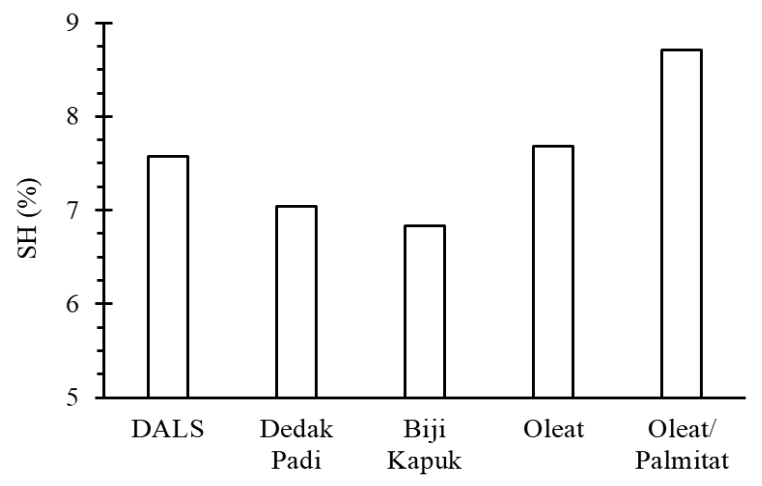

Gambar 4. Pengaruh bahan baku terhadap kadar merkaptan

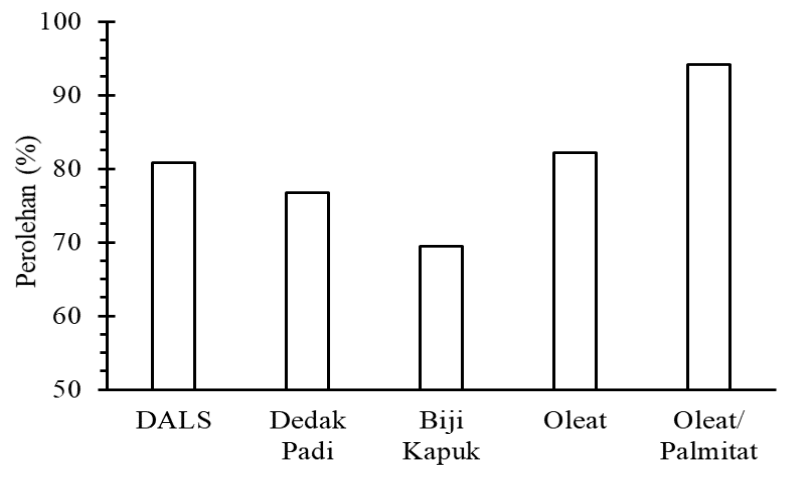

Gambar 5. Pengaruh bahan baku terhadap perolehan

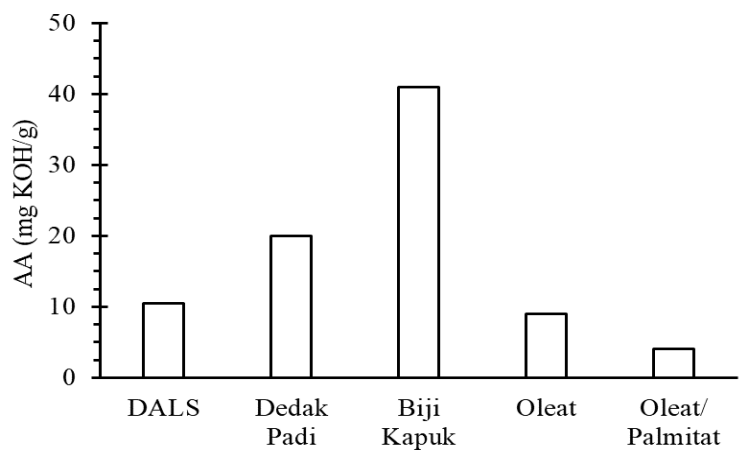

Gambar 6. Pengaruh bahan baku terhadap angka asam
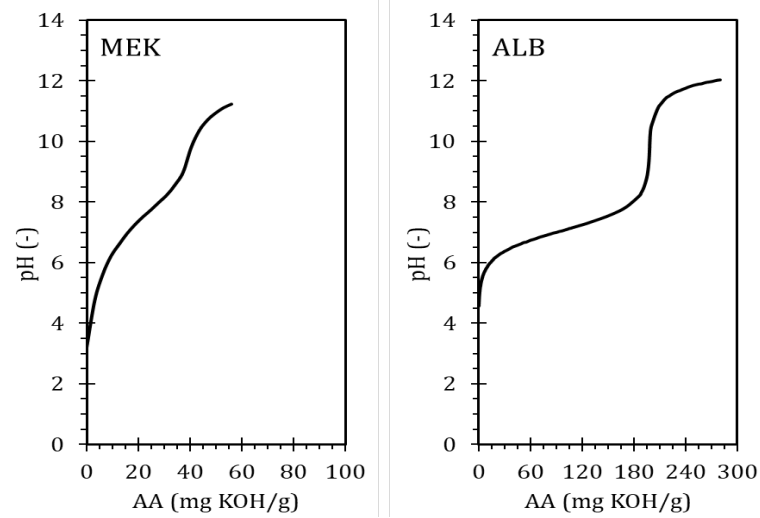

Gambar 7. Kurva titrasi angka asam MEK dan ALB

\section{Kesimpulan}

Merkapto etil karboksilat sebagai bahan baku stabiliser termal PVC telah disintesis dengan berbagai sumber asam lemak bebas, yang meliputi distilat asam lemat sawit, asam lemak dari minyak dedak padi dan asam lemak dari minyak biji kapuk. Pada rentang temperatur $60-80^{\circ} \mathrm{C}$, ketiga asam lemak memberikan produk dengan kadar merkaptan pada rentang 6,4-7,8\%. Temperatur $70^{\circ} \mathrm{C}$ merupakan temperatur terbaik. Pada temperatur ini, produk memiliki angka asam pada rentang 11-41 $\mathrm{mg} \mathrm{KOH} / \mathrm{g}$ dan perolehan pada rentang $70-81 \%$. Ketiga sumber asam lemak memberikan produk dengan kadar merkaptan yang mencukupi untuk dapat digunakan sebagai bahan baku stabiliser PVC. Mempertimbangkan kualitas produk dan ketersediaan di 
pasaran, distilat asam lemak sawit dipandang sebagai bahan baku yang paling baik.

\section{Ucapan Terima Kasih}

Ucapan terima kasih disampaikankan kepada Badan Pengelola Dana Perkebunan Sawit (BPDS) atas dana yang diberikan untuk mendukung penelitian dengan bahan baku distilat asam lemak sawit.

\section{Daftar Notasi \\ SH : kadar merkaptan (\%-b) \\ AA : angka asam $(\mathrm{mg} \mathrm{KOH} / \mathrm{g})$ \\ $\lambda \quad$ : panjang gelombang $\left(\mathrm{cm}^{-1}\right)$}

\section{Daftar Pustaka}

Ali, A.; Devarajan, S., Nutritional and Health Benefits of Rice Bran Oil. Brown Rice, 2017, 135-158.

Anigo, K.; Dauda, B.; Sallau, A.; Chindo, I., Chemical Composition of Kapok (Ceibapentandra) Seed and Physicochemical Properties of its Oil. Nigerian Journal of Basic and Applied Sciences, 2013, 21(2), 105-108.

\section{Badan Pusat Statistik, Luas Areal Tanaman Perkebunan} Rakyat Menurut Jenis Tanaman, https://www.bps.go.id/statictable/2013/12/31/1669/luasareal-tanaman-perkebunan-rakyat-menurut-jenistanaman-2000-2018-.html (akses 7 Desember 2018).

Berry, S.K., The Characteristics of the Kapok (Ceiba pentadra, Gaertn.) Seed Oil. Pertanika, 1979, 2(1), 1-4.

Carraher, C.E., Introduction to Polymer Chemistry, $3^{\text {rd }}$ ed. Florida: CRC Press, 2013.

Ceresana, Polyvinyl Chloride, $4^{\text {th }}$ ed. Konstanz: Ceresana Market Intelligence, 2017.

Chang, A.S.; Sherazi, S.T.H.; Kandhro, A.A.; Mahesar, S.A.; Chang, F.; Shah, S.N.; Laghari, Z.H.; Panhwar, T., Characterization of Palm Fatty Acid Distillate of Different Oil Processing Industries of Pakistan. Journal of Oleo Science, 2016, 65(11), 897-901.

Ciesielski, W.; Zakrzewski, R., Iodimetric Titration of Sulfur Compounds in Alkaline Medium. Chemia Analityczna, 2006, 51, 653-678.

Critchfield, F.E., Organic Functional Group Analysis. London: Elsevier, 1963.

Erliyanti, N.K., Karakteristik Biodiesel dari Minyak Biji Randu (Ceiba Pentandra) pada Reaktor Batch Berpengaduk Bertekanan Menggunakan Katalis $\mathrm{KOH}$. Journal of Research and Technologies, 2016, 2(1), 2327.

Fajar, A.S.; Hendrawati, T.Y., Proses Pengolahan Minyak Biji Kapuk (Ceiba Pentandra) Menjadi Methil Ester Melalui Proses Esterifikasi Transesterifikasi dengan Variabel Konsentrasi Katalis Koh dan Waktu
Reaksi. Seminar Nasional Sains dan Teknologi Universitas Muhammadiyah 2015, Jakarta, 17 November, 2015.

Leistner, W.E.; Hecker, A.C., Polyvinyl Chloride and Alkyl Tin Mercaptoalcohol Monocarboxylic Acid Esters. Patent US2870119 (A), 1959.

Machado, T.O.; Sayer, C.; Araujo, P.H.H., Thiol-Ene Polymerisation: A Promising Technique to Obtain Novel Biomaterials. European Polymer Journal, 2017, 86, 200 215.

Palm Oil Analytics, Palm Price Tracker. http://www.palmoilanalytics.com/price/15 dan http://www.palmoilanalytics.com/price/18 (akses 1 Maret 2019).

Patel, M.; Naik, S.N., Gamma-oryzanol from Rice Bran Oil - A Review. Journal of Scientific \& Industrial Research, 2004, 63, 569-578.

Putrawan, I.D.G.A.; Azharuddin, A.; Arum, K.R.; Adityawarman, D.; Rahim, D.A., Synthesis of Mercapto Ethyl Ester of Palm Fatty Acid Distillate. MATEC Web of Conferences, 2018, 156, 06010.

Shahidi, F., (Ed.), Bailey's Industrial Oil and Fat Products. Hoboken: John Wiley \& Sons, Inc., 2005.

Sonnet, P.E.; Moore, G.G., Thiol Esters of 2Mercaptoethanol and 3-mercapto-1,2-propanediol. Lipids, 1989, 24(8), 743-745.

Top, A.G.M., Production and Utilization of Palm Fatty Acid Distillate (PFAD). Lipid Technology, 2010, 22(1), 11-13.

Vedharaj, S.; Vallinayagam, R.; Yang, W.M.; Chou, S.K.; Chua, K.J.E.; Lee, P.S., Experimental Investigation of Kapok (Ceiba pentandra) Oil Biodiesel As An Alternate Fuel for Diesel Engine. Energy Conversion and Management, 2013, 75, 773-779.

Vogel, A.I.; Mendham, J., Vogel's Textbook of Quantitative Chemical Analysis. New Jersey: Prentice Hall, 2000.

Wallenwein, G., PVC Stabilizers: A Contribution to Sustainability. Plastics, Additives and Compounding, 2006, 8(5), 26-28.

Wang, A.; Li, J.; Li, J.; Zhong, X.; Long, S., Study on Synthesis Technology of Mercaptoethyl Oleate. Plastics Additives, 2012, 9(1), 34-37.

Wirth, H.O.; Andreas, H., The Stabilization of PVC Against Heat and Light. Pure and Applied Chemistry, 1977, 49, 627-648.

Wypych, G., PVC Degradation \& Stabilization, $2^{\text {nd }}$ ed. Toronto: ChemTec Publishing, 2008. 